\title{
Statistical screening of process variables for the production of L-asparaginase from cornflour by Aspergillus terreus MTCC 1782 in submerged fermentation
}

\author{
G. Baskar ${ }^{1}$ and S. Renganathan ${ }^{2}$
}

\author{
${ }^{1}$ Department of Biotechnology, St. Joseph's College of Engineering, Chennai - 600119, India \\ ${ }^{2}$ Dept. of Chemical Engg., Alagappa College of Technology, Anna University Chennai, Chennai - 600025, India \\ rengsah@rediffmail.com
}

Abstract: L-asparaginase has been used as anti-tumor agent for the effective treatment of acute lymphoblastic leukemia and as food processing aid to reduce the formation of acrylamide during frying of starchy foods at high temperature. Objective of the present work was to study the effect of process variables such as cornflour (as natural substrate), urea (as supplementary nitrogen source), L-asparagine, glucose, di-potassium hydrogen phosphate, potassium chloride, inoculum size and $\mathrm{pH}$ on the production of extracellular L-asparaginase by Aspergillus terreus MTCC 1782 in shake culture fermentation. The effect and significance of these variables was studied using 2-level Plackett-Burman statistical design. The experimental L-asparaginase activity was subjected to statistical analysis using MINITAB 14 software. It was found that L-asparagine, cornflour and urea significantly influenced as most important factors on L-asparaginase production.

Keywords: Extracellular L-asparaginase, acute lymphoblastic leukemia, food processing aid, PlackettBurman design, fermentation.

Introduction

L-asparaginase (L-asparagine amidohydrolase; EC.3.5.1.1) catalyzes the deamidation of $L$-asparagine to L-aspartic acid and ammonia. Colaspase, Crasnitin and Porton asparaginase are synonyms and Elspar, Oncaspar, Erwinase and Kidrolase are trade names of Lasparaginase. Although Clementi in 1922 had reported its presence in guinea-pig serum, the anti-tumour properties of the enzyme were only recognized sometime later (Bilimoria, 1969). Tsuji first reported Deamidation of Lasparagine by extracts of $E$. coli in 1957. Broome in 1961 discovered that the regression of lymphosarcoma transplants in mice treated with guinea-pig serum was due to the nutritional dependence of the malignant cells on exogenous L-asparagine (Wriston \& Yellin, 1973; Pritsa et al., 2001). Commercial production of Lasparaginase appeared desirable only after Mashburn and Wriston in 1973 showed that L-asparaginase from $E$. coli inhibits tumors in mice.

L-asparaginase is used as a chemotherapeutic agent for acute lumphocytic leukeamia and less frequently for acute myeloblastic leukeamia, chronic lumphocytic leukeamia, Hodgkin's disease, melonosarcoma and nonHodgkin's lymphoma. Various bacteria such as, E. coli (Howard \& Schwartz, 1968), Erwinia aroideae (Peterson \& Ciegler, 1969), Proteusvulgeris (Tosa et al., 1971), Streptomyces griseus (Dejong, 1972), Vibrio succinogenes (Kafkewitz \& Goodmanet, 1974), Citrobacter freundi (Davidson et al., 1977), Thermus aquaticus (Curran et al., 1985), Enterobacter aerogenes (Mukherjee et al 2000), Thermus thermophilus (Pritsa et al., 2001), Zymomonas mobilis (Pinheiroet et al., 2001) abd Pseudomonas aeruginosa (Abdel-Fatta Yasser et al., 2002) found to produce L-asparaginase. L-asparaginase has also been found in variety of fungi, yeasts and algae. L-asparaginase produced by bacteria leads to adverse side effects in human trials. Therefore, there is a search for the other sources of L-asparaginase production. It has been observed that eukaryotic microorganisms like yeast and filamentous fungi genera such as Aspergillus, Penicillium and Fusarium are commonly reported in scientific literature to produce asparaginase with less adverse effects (Sarquis et al., 2004). Since the optimization of nutritional requirements and operating conditions is an important step for bioprocess development. In addition, traditional method of bioprocess development by studying the effect of one variable at a time is tedious, time consuming and expensive. The demand for L-asparaginase will increase several fold in coming years due to its potential application in food processing addition to its clinical applications (Krishnan et al., 1998; Soliman et al., 2005; Pedreschi et al., 2008). Developing an economically viable bioprocess using with low cost substrates is an important step in any bioprocess development.

This research work was aimed to evaluate the effect of medium components and operating conditions on the production of extracellular L-asparaginase by Aspergillus terreus MTCC 1782 in shake culture fermentation using two levels Plackett-Burman (PB) statistical design uing cornflour as substrate.

Materials and Methods

Microorganism

The filamentous fungus selected to use throughout this study is Aspergillus terreus MTCC 1782 and was obtained from Institute of Microbial Technology, Chandigarh, India.

\section{Stock and inoculum culture conditions}

The spores and mycelial fragments of Aspergillus terreus MTCC 1782 strain was cultivated in Czapek agar slants at $37^{\circ} \mathrm{C}$ for 4 days. Czapek-Dox medium contains the following ingredients ( $\mathrm{g} / \mathrm{l}$ of distilled water). Solution $\mathrm{A}$ : L-asparagine, 10.0; sodium nitrate 40.0; potassium chloride 10.0; $\mathrm{MgSO}_{4} .7 \mathrm{H}_{2} \mathrm{O}, 0.52 ; \mathrm{FeSO}_{4} .7 \mathrm{H}_{2} \mathrm{O}, 0.2$; dissolved in one litre of distilled water and stored in refrigerator. Solution B: $\mathrm{K}_{2} \mathrm{HPO}_{4} 20.0$; dissolved in 1 litre of distilled water and stored in refrigerator. Solution $\mathrm{C}$ : one gram of $\mathrm{ZnSO}_{4} .7 \mathrm{H}_{2} \mathrm{O}$ dissolved in $100 \mathrm{ml}$ of distilled water. Solution D: 0.5 gram of $\mathrm{CuSO}_{4} . \mathrm{H}_{2} \mathrm{O}$ dissolved in
Research article

Clndian Society for Education and Environment (iSee)
"Asparaginase"

http://www.indjst.org
Baskar \& Renganathan Indian J.Sci.Technol. 
$100 \mathrm{ml}$ of distilled water. For one litre of Czapek-Dox medium; $50 \mathrm{ml}$ of solution $\mathrm{A}, 50 \mathrm{ml}$ of solution $\mathrm{B}, 1 \mathrm{ml}$ of both solution $\mathrm{C}$ and solution $\mathrm{D}, 900 \mathrm{ml}$ of distilled water, 30 gram of Glucose and 20 gram of agar were taken. Aspergillus terreus 1782 strain was cultivated in Czapek agar slants at $37^{\circ} \mathrm{C}$ for 4 days.

\section{Plackett-Burman design}

PB design is an efficient screening design when main effects are to be considered. It is used for experiments confronted with two-factor interaction. This is a very economical design with the run number a multiple of four and comprises of two level screening designs. This

Table 1. Actual values of the process variables

\begin{tabular}{|c|c|c|c|c|c|c|c|c|}
\hline $\begin{array}{c}\text { Process variables, } \\
\%(\mathrm{w} / \mathrm{v})\end{array}$ & $\begin{array}{c}\text { Corn } \\
\text { Flour }\left(\mathrm{X}_{1}\right)\end{array}$ & $\begin{array}{c}\text { Urea } \\
\left(\mathrm{X}_{2}\right)\end{array}$ & $\begin{array}{c}\mathrm{L} \text {-asparagine } \\
\left(\mathrm{X}_{3}\right)\end{array}$ & $\begin{array}{c}\text { Glucose } \\
\left(\mathrm{X}_{4}\right)\end{array}$ & $\begin{array}{c}\mathrm{K}_{2} \mathrm{HPO}_{4} \\
\left(\mathrm{X}_{5}\right)\end{array}$ & $\begin{array}{c}\mathrm{pH} \\
\left(\mathrm{X}_{6}\right)\end{array}$ & $\begin{array}{c}\text { Inoculum size } \\
\left(\mathrm{X}_{7}\right) \mu \mathrm{\mu l}\end{array}$ & $\begin{array}{c}\mathrm{KCl} \\
\left(\mathrm{X}_{8}\right)\end{array}$ \\
\hline Low Level $(-1)$ & 1 & 1 & 0.5 & 0.1 & 0.1 & 4.5 & 1000 & 0.025 \\
\hline High Level $(+1)$ & 2 & 2 & 1 & 0.2 & 0.2 & 6.5 & 2000 & 0.050 \\
\hline
\end{tabular}

\section{Production and isolation of crude enzyme}

Spore suspension was prepared from the inoculum culture, using $10 \mathrm{ml}$ of sterile water. This spore suspension with spore count of $2^{*} 10^{7}$ to $10^{8}$ per $\mathrm{ml}$ was transferred to Erlenmeyer flasks with $100 \mathrm{ml}$ of liquid Czapek-Dox medium prepared based on PB statistical design (Table 2) and kept in orbital shaker at $160 \mathrm{rpm}$ for 4 days. Then culture was filtered on Whattman 2 filter paper and the cell-free filtrate was used as crude enzyme solution (Prista et al., 2001).

\section{Assay of L-asparaginase activity}

Enzyme activity of the culture filtrates was determined at the end of cultivation time by quantifying ammonia formation in a spectrophotometric analysis using Nessler's Reagent. Nesslarization is the most commonly used method for estimation of L-asparaginase activity. The quantity of ammonia formed during the hydrolysis of $0.04 \mathrm{M}$ L-asparagine was estimated using Nessler's Reagent in spectrophotometric analysis at $480 \mathrm{~nm}$ (Wriston \& Yellin, 1973). design is extremely useful in finding importance of the factors affecting the production of the enzyme. PB design offers a good and fast screening procedures and mathematically computes the significance of a large number of factors in one experiment, which is time saving and gives the effect of change in more than one factors in single experiment (Krishnan et al., 1998; AbdelFatta Yasser et al., 2002; Soliman et al., 2005; Pedreschi et al., 2008). To evaluate the effect of 8 factors of medium components and operating conditions on L-asparaginase activity PB factorial design in 12 experimental run was carried out.

Eight assigned variables and three unassigned variables (commonly referred as dummy variables) were screened in PB design of 12 experiments. Dummy variable are used to estimate experimental errors in data analysis (Abdel-Fatta Yasser et al., 2002; Soliman et al., 2005). Eight factors consisting of medium components and operating conditions prepared at two levels -1 for low level and +1 for high level. The factors (in $\mathrm{gm} / 100 \mathrm{ml}$ ) such as Cornflour $\left(\mathrm{X}_{1}\right)$, Urea $\left(\mathrm{X}_{2}\right)$, L-asparagine $\left(\mathrm{X}_{3}\right)$, Glucose $\left(X_{4}\right), \mathrm{K}_{2} \mathrm{HPO}_{4}\left(\mathrm{X}_{5}\right), \mathrm{pH}$ $\left(X_{6}\right)$, Inoculum size in $\mu \mathrm{l}\left(X_{7}\right)$, and $\mathrm{KCl} \quad\left(\mathrm{X}_{8}\right)$ and 3 unassigned variables at same level were studied. The actual values of the variables at low level $(-1)$ and high level $(+1)$ is given in Table 1. Table 2 shows the factors considered for investigation and the PB design for 12 experimental run and the experimental L-asparaginase activity. PB experimental design is based on the first order model as given in equation 1.

$$
Y=\beta_{0}+\sum \beta_{\mathrm{i}} \mathrm{x}_{\mathrm{i}}
$$

Where, $Y$ is the response (enzyme activity), $\beta_{0}$ is the model intercept, $\beta_{\mathrm{i}}$ is variable estimates and $X_{i}$ are independent variables. This model describes
12

$-1$

Research article

CIndian Society for Education and Environment (iSee)
Baskar \& Renganathan "Asparaginase" http://www.indjst.org 
no interaction among the factors that influence asparaginase production and enzyme activity. All experiments were carried out in duplicate and the averages of L-asparaginase activity was taken as responses. The variables whose confidence levels were higher than $90 \%$ were considered that significantly influences the Lasparaginase activity.

Results and Discussion

Evaluation of medium components and operating conditions by Plackett-Burman design

The data on enzyme activity in Table 2

Table 3. Statistical analysis of Plackett-Burman design on L-asparaginase activity

\begin{tabular}{|c|c|c|c|c|c|}
\hline Variable & $\begin{array}{c}\text { Main } \\
\text { effect }\end{array}$ & Coefficients & t-value & p-value & $\begin{array}{c}\text { Confidence } \\
\text { level, \% }\end{array}$ \\
\hline Intercept & & 21.836 & 21.56 & 0.000 & \\
\hline $\mathrm{X}_{1}$ & 4.426 & 2.213 & 2.18 & 0.117 & 88.3 \\
\hline $\mathrm{X}_{2}$ & 3.093 & 1.546 & 1.53 & 0.224 & 77.6 \\
\hline $\mathrm{X}_{3}$ & 10.772 & 5.386 & 5.32 & 0.013 & 98.7 \\
\hline $\mathrm{X}_{4}$ & -0.320 & -0.160 & -0.16 & 0.885 & 11.5 \\
\hline $\mathrm{X}_{5}$ & -1.066 & -0.533 & -0.53 & 0.635 & 46.5 \\
\hline $\mathrm{X}_{6}$ & -1.493 & -0.746 & -0.74 & 0.515 & 48.5 \\
\hline $\mathrm{X}_{7}$ & -0.800 & -0.400 & -0.39 & 0.719 & 18.1 \\
\hline $\mathrm{X}_{8}$ & -3.093 & -1.547 & -1.53 & 0.224 & 77.6 \\
\hline
\end{tabular}

Table 4. Analysis of variance (ANOVA) for linear model on effect of independent variables on $L$-asparaginase production

was subjected to multiple linear
regression analysis using MINITAB 14 software to estimate t-value, $p$-value and confidence level. The data on Lasparaginase activity using $\mathrm{PB}$ experiments showed a wide variation from 11.678 to $31.355 \mathrm{IU} / \mathrm{ml}$ of $\mathrm{L}$ asparaginase activity.

On analysis of regression coefficients and t-value of 8 factors

\begin{tabular}{|l|c|c|c|c|c|}
\hline Source & $\begin{array}{c}\text { Degree of } \\
\text { freedom (DF) }\end{array}$ & $\begin{array}{c}\text { Sum of } \\
\text { squares (SS) }\end{array}$ & $\begin{array}{c}\text { Mean } \\
\text { square (MS) }\end{array}$ & F-value & p-value \\
\hline Main effects & 8 & 476.57 & 59.57 & 4.84 & 0.111 \\
\hline $\begin{array}{l}\text { Residual } \\
\text { error }\end{array}$ & 3 & 36.94 & 36.94 & & \\
\hline $\begin{array}{l}\text { Total sum of } \\
\text { squares }\end{array}$ & 11 & 513.51 & & & \\
\hline
\end{tabular}

an important diagnostic tool to detect and explain the cornflour $\left(\mathrm{X}_{1}\right)$, urea $\left(\mathrm{X}_{2}\right)$ and L-asparagine $\left(\mathrm{X}_{3}\right)$ showed a positive effect on $L$-asparaginase production, all other factors shown a negative effect on L-asparaginase production. The t-test for any individual effect allows an evaluation of the probability of finding the observed effects purely by chance. In this work, variables with confidence levels greater than $90 \%$ were considered as significant. L-asparagine was found to be highly significant factor for L-asparaginase production (Table 3 ). Estimated t-value, P-value and confidence level for Lasparaginase activity was shown in Table 3 . On the basis of the calculated t-values, $p$-values and confidence level given in table 3, L-asparagine (confidence level- 98.7\%), cornflour (confidence level - 88.3\%), urea (confidence level- $77.6 \%$ ) and potassium chloride (confidence level$77.6 \%$ ) were found as most important factors influences the L-asparaginase production and the optimum level of these variables can be determined by response surface methodology in further study. Table 4 shows the Analysis of Variance (ANOVA) for linear model on effect of independent variables on L-asparaginase production.

The effect of significant and most important variables on L-asparaginase activity is given by the model in equation 2.

$\mathrm{Y}=21.836+2.213 \mathrm{X}_{1}+1.546 \mathrm{X}_{2}+5.386 \mathrm{X}_{3}-1.547 \mathrm{X}_{8}$

The effect of medium components and operating conditions on L-asparaginase activity was also studied using pareto chart (Fig. 1). L-asparagine $\left(X_{3}\right)$ was found to be the significant factor and the cornflour $\left(X_{1}\right)$, urea $\left(X_{2}\right)$ and potassium chloride $\left(X_{8}\right)$ were found to be other most important factors on L-asparaginase production.

Fig. 2, the normal probability plot of the residuals is

Research article

CIndian Society for Education and Environment (iSee)
"Asparaginase"

http://www.indjst.org systematic departures from the assumptions. The residual was plotted against normal distribution of the model and it is approximate linear line for -asparaginase production. That the errors are normally distributed and are independent of each other and that the error variances are homogenous. An excellent normal distribution confirmed the normality assumption and the independence of the residuals. This indicates that the model was well fitted with the experimental results. As the residuals from the fitted model are normally distributed, all the major assumptions of the model have been validated. The residual plot in Fig. 3, shows equal scatter of the residual data above and below the $x$-axis indicates that the variance was independent of the L-asparaginase activity, thus supporting the adequacy of the model fit.

\section{Conclusion}

Stepwise statistical optimization strategy such as Plackett-Burman offers a good and fast screening procedure and identifies the influence of more than one factor in single experiment. The effect of media components and operating conditions on the production of L-asparaginase by Aspergillus terreus MTCC 1782 were studied using PB design and it was found that Lasparagine, cornflour, urea and potassium chloride significantly influences and most important factors on the L-asparaginase production within their tested limits. The optimum level of these variables can be determined using response surface methodology in further research.

Nomenclature

ANOVA - Analysis of variance, $F$ - Fishers's function, i variable number, IU - International unit, $p$ - corresponding level of significance, B - Plackett-Burman, $t$ - student's 
test, $\mathrm{X}_{\mathrm{i}}$ - independent variables, $\mathrm{Y}$ - predicted response, $\beta_{0}$ - model intercept, $\beta_{\mathrm{i}}$ - variable estimate.

Fig. 1. Effect of medium components and operating conditions on Lasparaginase activity

(Response is L-asparaginase activity, IU $/ \mathrm{mL}$, Alpha $=0.10$ )

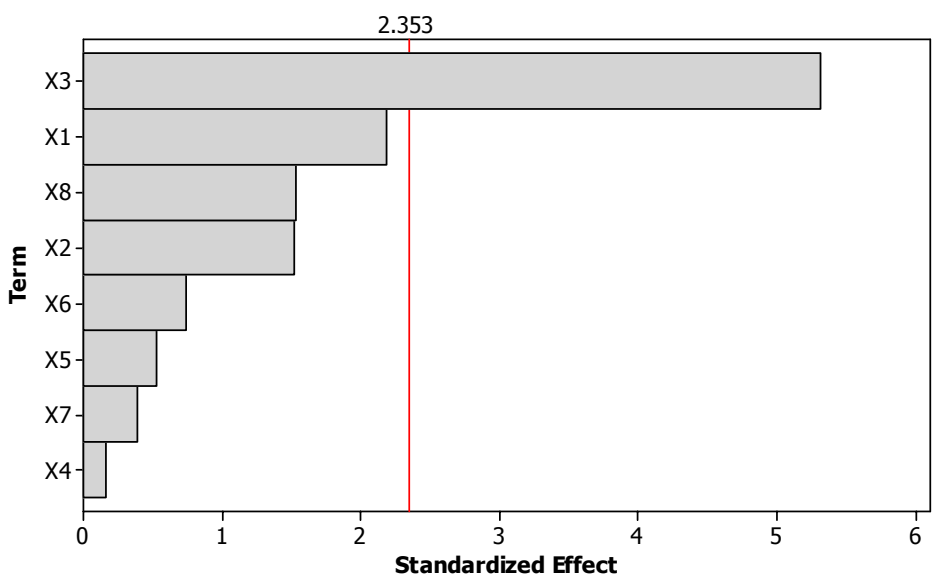

Fig. 2. The Normal probability plot for L-asparaginase activity (Response is L-asparaginase activity, IU/mL)

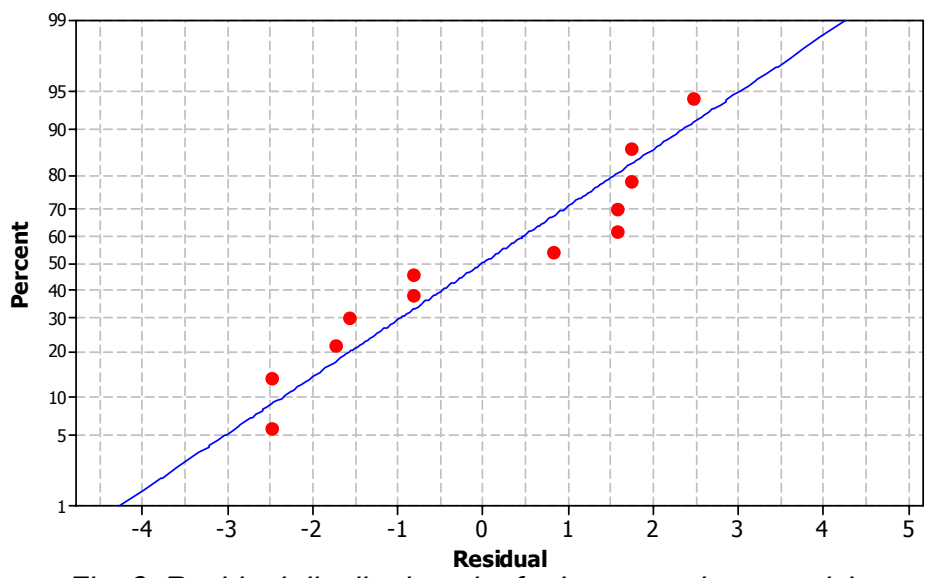

Fig. 3. Residual distribution plot for L-asparaginase activity (Response is L-asparaginase activity, IU/mL)

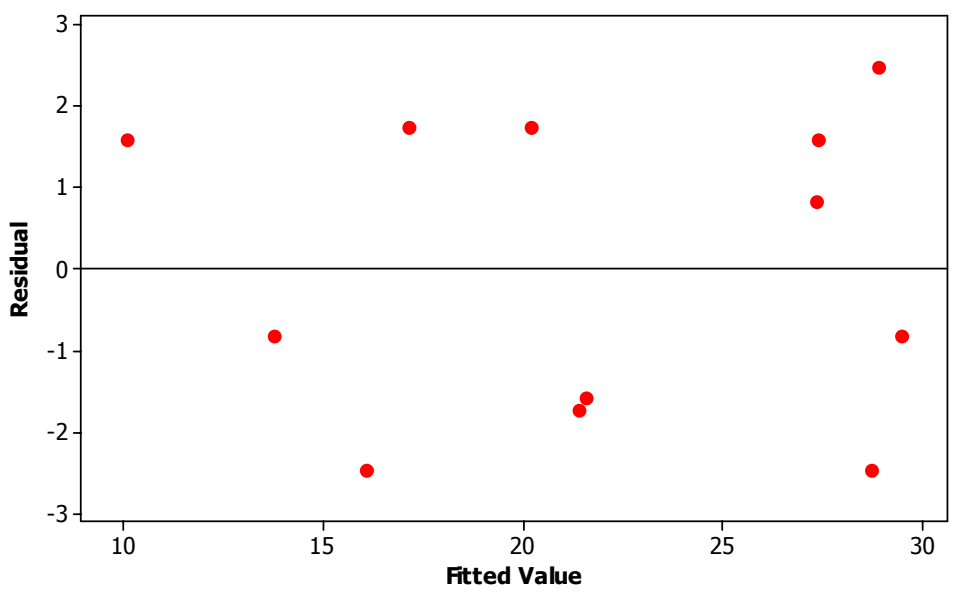

\section{References}

1. Abdel-Fatta Yasser R, Soliman Nadia A, Gaballa Ahmed A, Sabry Soraya A and El-Diwany Ahmed I (2002) Lipase production from a novel thermophilic Bacillus $s p$ :
Vol.2 No 5 (May 2009)

ISSN: 0974- 6846

Application of Plackett Burman design for evaluating culture conditions affecting enzyme formation. Acta Microbiologica Polonica. 51, 353-366.

2. Bilimoria $\mathrm{MH}$ (1969) Conditions for the production of L-asparaginase by coliform bacteria. Appl. Microbiol. 18, 1025-1030.

3. Curran MP, Daniel RM, Guy GR and Morgan HW (1985) A specific L-asparaginase from Thermus aquaticus. Arch. Biochem. Biophys. 241, 571-576.

4. David Kafkewitz and David Goodmanet (1974) Asparaginase production by the rumen anaerobe Vibriosuccinogenes. Appl. Microbiol. 27, 206-209.

5. Davidson L, Burkom M, Ahn S, Chang LC and Kitto B (1977) L-Asparagainases from Citrobacter freundii. Biochim. Biophys. Acta. 480, 282-294.

6. Dejong (1972) L-Asparaginase production by Streptomyces griseus. Appl. Microbiol. 23, 1163-1164.

7. Howard C and Schwartz JH (1968) Production of Lasparaginase II by Escherichia coli. J. Bacteriol. 96, 2043-2048.

8. Joint FAO/WHO Expert Committee on Food Additives (JECFA) (2001) Compendium of food additive specifications. General specifications and considerations for enzyme preparations used in food processing. FAO Food \& Nutr. 52 (9), 37-39.

9. Krishnan S, Prapulla S G, Rajalakshmi D, Misra MC and Karanth NG (1998) Screening and selection of media components for lactic acid production using Plackett-Burman design. Bioprocess Eng. 19, 61-65.

10. Mukherjee J, Majumdar $S$ and Scheper T (2000) Studies on nutritional and oxygen requirements for production of L-asparaginase by Enterobacter aerogenes. Appl. Microbiol. Biotechnol. 53, 180-184.

11. Pedreschi F, Kaack K and Granby K (2008) The effect of Asparaginase on acrylamide formation in French fries. Food Chem. 109, 386-392.

12. Peterson RE and Ciegler A (1969) L-asparaginase production by Erwinia aroidae. Appl. Microbiol. 18, 6467.

13. Pinheiro $\mathrm{IO}$, Araujo JM, Ximenes ECPA and Pinto JCS (2001) Production of L-asparaginase by Zymomonas mobilis strain CP4. Biomaterial \& Diagnostic, 6, 243-244.

14. Pritsa AA, Papazisis KT, Kortsaris AH, Geromichalos GD and Kyriakidis D (2001) Antitumor activity of Lasparaginase from Thermus thermophilus. Anticancer Drugs. 12, 137-142.

15. Sarquis MIM, Oliveira EMM, Santos AS and Costa GL (2004) Production of L-asparaginase by filamentous fungi. Mem. Inst. Oswaldo Cruz. 99, 489-492.

16. Soliman Nadia A, Berekaa Mahmoud N and AbdelFattah Yasser R (2005) Polyglutamic acid production by Bacillus sp. SAB-26: application of PlackettBurman experimental design to evaluate culture requirements. Appl. Microbiol. Biotechnol. 69, 259-67.

17. Tosa T, Sano R, Yamamoto K, Nakamura M and Chibata I (1971) L-asparaginase from Proteus vulgaris. Appl. Microbiol. 22, 387-392.

18. Wriston JC and Yellin TO (1973) L-asparaginase - A review. Adv. Enz. 39, 185-248. 